\title{
Obituaries
}

Obituaries should be submitted by email to Kate Maynard at k.maynard@nature.com.

All submitted obituaries should be 350 words maximum in length (apart from obituaries for past presidents of the BDA where the length should be $700-800$ words).

Content of the obituary is down to the individual author, and the approval of the family should be given for the obituary prior to submission to the $B D J$.

\section{RALEIGH BARCLAY LUCAS}

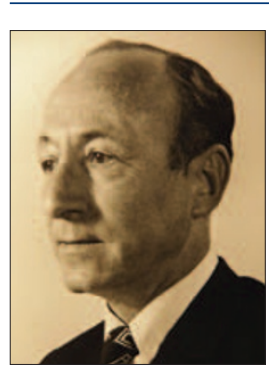

Raleigh Barclay

Lucas, Emeritus

Professor of Oral

Pathology, died on

11 October 2011. He

was a distinguished

oral pathologist

and academic and

for 15 years was

the Dean of the Royal Dental Hospital

School of Dental Surgery.

He was born in Edinburgh in 1914

and educated at George Watson's

School. He read medicine at the University of Edinburgh and qualified in 1936. At the beginning of the Second World War he enrolled in the Royal Army Medical Corps (RAMC). Immediately before being posted to India he was responsible for immunising military personnel at the Radcliffe Royal Infirmary, Oxford. It was here that he vaccinated Violet, a member of the Queen Alexandra Nursing Corps, who later became his wife.

He followed an unusual career pathway. During his first posting to India, he isolated an outbreak of typhus fever for which he was promoted to Major. After the war Raleigh trained in general pathology at the Middlesex Hospital. Following this he worked at Stoke Mandeville Hospital and in 1949 was encouraged to apply for a post at The Royal Dental Hospital School of Dental Surgery. He developed the department of Oral Pathology to a level of international recognition. In 1952 he was appointed as Professor of Oral Pathology.

He was most well known for his textbook Pathology of tumours of the oral tissues, first published in 1963.
This has now reached its fifth edition and is published as Lucas's pathology of tumours of the oral tissues and is authored by several distinguished colleagues. Raleigh published other textbooks and authored several WHO handbooks on different aspects of oral tumours. With Alan Thackaray he produced a handbook for the US Armed Forces on pathology of tumours of the salivary glands. He continued to work up to his 86th year.

He was a man of exquisite good manners who was regarded by colleagues and students as a kind and thoughtful man, always concerned for the needs of his staff.

Raleigh was predeceased by his son David. He leaves Violet, his wife of over 70 years, and his daughter, Victoria.

Victoria S. Lucas and Graham J. Roberts

\section{DEREK CHARLES DEBUSE}

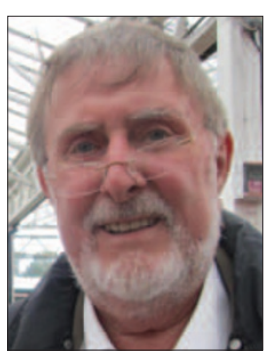

Derek Charles Debuse was born in London on 31 March 1944 and graduated from the Royal Dental Hospital in 1966. His furst appointment was as an associate dentist in Loughton. The following year he married Gill and moved to Bognor Regis. From 1974 until his retirement in 2008 Derek was a principal in a large family dental practice in Billingshurst.

In 1975 Derek became a part-time Demonstrator at the Royal Dental and, following its merger with Guy's in 1985, was promoted to Senior Demonstrator in Conservative Dentistry at the newly formed 'United Medical and Dental Schools' (UMDS). With his keen interest in pain and anxiety control, in 1989 Derek was appointed as a Senior Demonstrator in the Department of Sedation and Special Care Dentistry, a position he held until his retirement in 2008.

Derek was a skilful and caring clinician who inspired thousands of students. In the mid-nineties Derek became Honorary Secretary and then Chairman of the Dental Sedation Teachers Group. In 2005 he was elected Honorary Secretary of the Society for the Advancement of Anaesthesia in Dentistry. He was an examiner for the National Examining Board for Dental Nurses for nearly two decades. Derek will also be remembered as the Secretary of the Royal Dental Hospital 'Old Students and Staff Association' (OSSA) and, later, the Honorary Treasurer of the 'KCLDI Alumni Association'.

Derek's professional achievements have been nationally recognised. He was awarded honorary life membership of both the BDA and SAAD. In addition, in 2011 KCLDI conferred upon him their 'Distinguished Service Award'.

Away from his professional activities, Derek was an accomplished pianist and chairman of the Bognor Regis Music Club for 33 years.

Derek made an outstanding contribution to his profession and the care of patients. He died on 10 December 2011 at the age of 67 , following a long-standing illness, which he bore with great fortitude. He will be greatly missed by his wife, Gill, his children, Maddy and Stuart and all of us who had the great good fortune to be influenced by his knowledge, commitment, dignity and charm.

David Craig 